\title{
Mechanism of action of triclosan as an endocrine-disrupting chemical with its impact on human health - literature review
}

\author{
Marcela Maksymowicz ${ }^{1, A-D, F \oplus}$, Piotr Artur Machowiec ${ }^{1, A-D \oplus}{ }^{\circ}$, Gabriela Ręka ${ }^{1, A, C-D \oplus}$, \\ Anna Korzeniowska ${ }^{1, C-D, F \oplus}{ }^{\text {, Patryk Leszczyk }}{ }^{1, C-D}{ }^{\oplus}$, Halina Piecewicz-Szczęsna ${ }^{1, E-F} \oplus$ \\ ${ }^{1}$ Chair and Department of Epidemiology and Clinical Research Methodology, Medical University, Lublin, Poland \\ A - Research concept and design, B - Collection and/or assembly of data, C - Data analysis and interpretation, \\ $D$ - Writing the article, E - Critical revision of the article, F-Final approval of the article
}

Maksymowicz M, Machowiec PA, Ręka G, Korzeniowska A, Leszczyk P, Piecewicz Szczęsna H. Mechanism of action of triclosan as an endocrinedisruptingchemical with its impact on human health. Literature review. J Pre-Clin Clin Res. 2021; 15(4): 169-175. doi: 10.26444/jpccr/142065

\begin{abstract}
Introduction and objective. Triclosan is a synthetic, aromatic organic chemical compound with antimicrobial properties. Due to its wide application as a preservative in cosmetics, antiperspirants, plastics, or surgical sutures, various mechanisms of TCS action on the human body are described. The study focus on the analysis of antimicrobial properties, effects on metabolism, immunity and the endocrine system, as well as carcinogenesis.

Review methods. The latest literature available on 13 June 2021 was reviewed by using the PubMed and Google Scholar databases. There were 34 papers selected for analysis after reading the abstracts, which met the assumed criteria.

Brief description of the state of knowledge. Triclosan can be used as an antimicrobial against bacteria such as Staphylococcus aureus, Mycobacterium tuberculosis. However, over-exposure to TCS can also contribute to the acquisition of resistance in bacteria. Interestingly, triclosan as an endocrine disrupting chemical (EDC) might disrupt thyroid, ovarian, or testis homeostasis, having a potential impact on reproductive health. TCS via an estrogen receptor signaling pathway can raise estrogen and progesterone secretion and promote development of hormone-dependent neoplasms, such as breast and ovarian cancer. The chemical has also potential to induce cell proliferation of prostate cancer cells. On the other hand, it contributes to apoptosis in Burkitt lymphoma-derived cells, which means that TCS can have antitumour properties.

Conclusion. Triclosan is a commonly usean antimicrobial agent in medical and consumer care products. Due to its unclear impact on organisms, further studies are necessary regarding both the use of TCS as an antibacterial agent and possible harmful effects on the human body.
\end{abstract}

\section{Key words}

triclosan, endocrine disrupting chemicals, carcinogenesis

\section{INTRODUCTION}

Triclosan (TCS, 5-chloro-2-(2,4-dichlorophenoxy)phenol) is a synthetic, aromatic organic chemical compound from the group of chlorinated phenols, used as an antimicrobial agent. In view of TCS antibacterial, antiviral, and antifungal properties, it is a compound used worldwide in personal care and household products $[1,2]$. It is commonly found in soaps, creams, and solutions for disinfection of the hands and wounds. Furthermore, it is regarded as a vital component of textiles, prosthetics, and surgical sutures [1].

Regarding the genesis of TCS, it was primarily patented in 1964 by the Swiss company Ciba-Geigy. After meeting safety standards, triclosan was initially used by hospitals, mainly due to its effective action against Gram-positive and most Gram-negative bacteria [3]. Over time, it began to be used as a component of triclosan-coated surgical sutures because of the effect on decreasing the risk of SSI (surgical site infection) [4, 5], a frequent complication of abdominal surgery. However, some reports proved that the action of TCS may cause Pseudomonas aeruginosa high triclosan tolerance [6]. For

Address for correspondence: Marcela Maksymowicz, Chair and Department of Epidemiology and Clinical Research Methodology, Radziwiłłowska 11, 20-080 Lublin, Poland

E-mail: marcela.maksymowicz@gmail.com

Received; 15.07.2021; accepted: 08.09.2021; first published: 28.09.2021 that reason, it has been increasingly used in combination therapy with other alcohols to achieve a synergistic effect, and to avoid the bacterial resistance mentioned above [7].

Nevertheless, despite its wide range of applications, more and more information is emerging regarding its endocrine disruption $[8,9]$. Systemic toxicity studies in mammals indicate that TCS is not mutagenic, carcinogenic, or toxic to their development, but it may impair hormones homeostasis, including HPT (hypothalmic-pituitary-thyroid) and HPG (hypothalamic-pituitary-gonadal) axes. On the contrary, based on some studies, TCS has a toxic effect on aquatic organisms by reducing their surveillance [10]. Other studies are investigating the effect of TCS on the immunity, metabolism, endocrine system, and carcinogenesis, to determine how triclosan exposure may negatively affect human health [11]. Recently, new rationales on a potential mechanism for its action have been defined, although none of them have been fully confirmed, and the majority are based on animal studies.

The latest literature available on 13 June 2021 was reviewed using the materials accessible in the PubMed and Google Scholar databases. The following inclusion criteria were applicable: papers published from 2015, in English, and available as fulltext publications. Original and review papers were referred to, letters to the editor, and papers with an annotation as 'preprint' were not included. The literature review was carried 
out on 13 June 2021, using the following keywords linked by logical operators: 'triclosan', 'metabolism', 'carcinogenesis' and 'endocrine system chemicals', after selection by two independent analysts. Subsequently, 34 scientific publications were selected for analysis by two independent analysts who read the abstracts which met the assumed criteria. A handsearching was performed on the reference list of retrieved studies to avoid omitting publications.

\section{OBJECTIVE}

The aim of the study is a presentation of the current state of knowledge regarding the mechanisms of action of triclosan as an endocrine-disrupting chemical and explains its potential impact on human health.

\section{DESCRIPTION OF THE STATE OF KNOWLEDGE}

Mechanism of action - Antimicrobial activity. Triclosan, due to its antibacterial, antiviral, and antifungal properties, is widely used as a preservative in cosmetics, soaps, mouthwashes, antiperspirants, kitchenware, textiles, bedding, electronics, plastics, and toys [1]. TCS is a highly effective broad-spectrum antimicrobial agent, which is able to inhibit the action of various microorganisms even at low concentrations. Also, at high concentrations it can have a bactericidal effect [12].

One way to use the antiseptic properties of TCS in medicine is to coat surgical sutures with it. Ahmed et al. performed a systematic review comparing the incidence of surgical site infections (SSIs) using triclosan-coated surgical sutures, and triclosan-free sutures for wound closure. There were 25 studies involving 11,957 patients included in the review. A total of 420 SSIs were diagnosed among 6,008 patients in the triclosan-coated suture group and 581 SSIs in 5,949 patients in the TCS-free suture group. The risk of developing SSIs was significantly reduced in the triclosan group compared to the standard suture group (RR $0.73,95 \%$ CI 0.65 to 0.82 ) in both clean and contaminated surgical procedures [13].

A cell membrane is the primary site of TCS activity and one of the first cellular obstacles it must overcome to exert its effects. It has been claimed that TCS interacts nonspecifically with the prokaryotic cell membrane, which could confirm the resistance of Gram-negative bacteria to TCS (it was associated with their outer membrane) [1]. As an antiseptic in low concentrations, TCS inhibits the synthesis of fatty acids, which are essential for the structure of the bacterial membrane and wall; in high concentrations, TCS directly destroys the bacterial membrane [14, 15]. TCSsensitive bacteria are: Staphylococcus aureus, Mycobacterium tuberculosis, Helicobacter pylori, Haemophilus influenzae. However, over-exposure to TCS can also induce resistance in bacteria, for example, resistance in Escherichia coli and Rhodospirillum rubrum S1H. During exposure to TCS, significant changes were observed in the expression patterns of genes involved in the cell wall and membrane structure, cell envelope, flagella, and multidrug efflux. Moreover, it was recently suggested that TCS binds to the transcriptional repressor AcrR, causing conformational changes and preventing its binding to the efflux pump AcrA promoter in Agrobacterium tumefaciens [1].
Zeng et al. investigated the effect of triclosan on drug resistance in Escherichia coli isolated from urine specimens in China. Of the $200 \mathrm{E}$. coli strains isolated from urine samples, 5 TCS-resistant strains (2.5\%) were isolated, and among them, multi-drug resistance (MDR), as well as cross-resistance phenotypes, were found. Moreover, exposure to triclosan of 5 sensitive $E$. coli isolates showed rapidly increasing resistance to this substance after in vitro exposure to TCS for only 12 days. The authors emphasize that exposure to TCS not only contributes to the acquisition of resistance to this substance, but also facilitates the reduction of sensitivity to clinical antimicrobials. For this reason, it is preferable to avoid the long-term use of TCS in clinical practice [12].

The extremely low solubility of TCS in water $(10 \mu \mathrm{g} / \mathrm{ml})$ has significantly limited its use in the treatment of bacterial infections [14]. Yang, et al. assesed whether the modification of TCS with nanomaterials could increase its antimicrobial effectiveness. Two supramolecular hydrogel nanoantibiotics based on triclosan were developed by its conjugation to self-assemble peptides. The obtained nanoantibiotics had many advantages: a stable three-dimensional structure of nanofibres, 850-fold increase in TCS solubility, acidresponsive TCS release, and favourable biocompatibility. Consequently, nanoantibiotics showed a broad spectrum of in vitro antibacterial activity against Gram-positive and Gram-negative bacteria, based on the interaction of the TCS antibiotic and nanostructure-induced destruction of the bacterial membrane. Moreover, they showed that treatment with the above antibiotics did not damage the haematopoietic cells or induce an inflammatory response [14].

Metabolism, immunity. Due to the widespread use of the antimicrobial TCS in consumer goods and its metabolites in the environment, TCS as a small chemical can be consumed and absorbed by humans through the skin and mucous membranes $[16,17]$. The substance can stimulate toll-like receptors (TLR), influence the skin microbiome, and may increase the risk of allergic diseases [16, 18]. In a recent in vivo study on female BALB/cAnNTac (BALB/c) mice cells, Weatherly et al. reported that proallergic activity is also possible by NLRP3 inflammasome activation, which can be caused by danger-associated molecular patterns (DAMPs), such as S100A8/A9 protein. TCS increased S100A8/A9 gene expression in the skin and in draining lymph nodes (dLNS). Interestingly, increased levels of S100A8/A9 and thymic stromal lymphopoietin (TSLP) resulted in exacerbating allergic reaction to ovalbumin in a mouse asthma model [18]. Furthermore, TCS-induced inflammasome activation led to chemokine release - Cxcl1/2, Ccl2, and Ccl19 in the $\mathrm{dLN}$ and $C x c l 1 / 2$ in the skin, as well as IL-1 $\beta$ release and dysfunction of mitochondria, confirmed by their altered morphology, decrease in mtMass and mitochondrial membrane potential (MMP). TCS-induced inflammasome activation led to chemokine release - Cxcl1/2, Ccl2, and Ccl19 in the dLN and Cxcl1/2 in the skin. In the mice model, TCS led to activation of the NLRP3 inflammasome by another pathway - increasing Drp1 and decreasing Opal expression [19]. The dynamin-related protein 1 (Drp 1) is associated with mitochondrial fission and the role of optic atrophy 1 (Opa1) is maintenance of the structure of the inner mitochondrial membrane [18].

Mitochondrial toxicity of TCS is related to inflammation and immunity [19]. Due to its proton ionophore nature, it 
depressed MMP in human Jurkat T cells. However, TCS did not affect PMP - plasma membrane potential, but induced acidifying the cytosol of mast cells as well as T lymphocytes. This resulted in uncoupling the STIM1/ORAI1 interaction, inhibition of the opening of plasma membrane $\mathrm{Ca}^{2+}$ channels, and inhibition of $\mathrm{Ca}^{2+}$ influx, which disrupted the function of the immune cells. Mitotoxicity, mitochondrial toxicity, and $\mathrm{Ca}^{2+}$ mobilization are part of mechanisms underlying TCS disrupting function of immune and neurological mast cells engaged in pathogenesis of such diseases as neoplasms and multiple sclerosis. TCS as a mitochondrial uncoupler contributed to the dysfunctions of primary human keratinocytes and mast cells [17]. In another study with in vitro human immortal keratinocyte cell line (HaCaT), TCS exposure led to the increase of purine and glutathione metabolism and decrease in amino acid metabolism. Additionally, TCS induced intercellular lipid dysregulation in keratinocytes. This led to oxidative stress - production of reactive oxygen species (ROS) and pro-inflammatory cytokines initiating apoptosis.

The immunomodulatory and pro-oxidative properties of TCS were identified in another study [10]. In fish exposed to TCS, phagocytic activity of leukocytes was reduced, which was associated with the decrease in respiratory burst activity (RBA), myeloperoxidase activity (MPO), and serum lysozyme activity. Reduction in RBA and lysozyme was probably related to dysfunction of protein synthesis in phagocytic cells, and production of immature leukocytes effector cells. The immunosuppressive action of TCS is also caused by liver damage and impaired synthesis of albumins and globulins, which negatively influences the function of lymphocytes. Moreover, inhibition of cellular and humoral immune response contributed to a higher mortality rate in infected groups of fish.

TCS may damage vascular endothelium, which is related to the development of cardiovascular diseases, such as ischemic heart disease, stroke, and hypertension [20]. TCSinduced increasing cytosolic $\left[\mathrm{Ca}^{2+}\right]$ levels, accumulation of mitochondrial ROS, and reducing MMP results in vascular relaxation in rat aortic smooth muscle cells. In zebrafish, TCS exposure reduced red blood cells and microvessels by regulating miR-181a-5p. TCS promoted the formation of ROS, which caused damage to DNA in red blood cells and normal cell division. In cultured human umbilical vein endothelial cells (HUVEC), TCS increased the expression of inflammatory markers - TNF-alpha, IL-6, IL-8, MCP-1, and cellular and mitochondrial ROS. Viability, migration, and angiogenesis of HUVEC were inhibited. Another mechanism of damage to HUVEC cells was inhibition of PI3K/Akt/ mTOR expression and enhanced caspase 3/7 activity.

Although TCS is used as an antibacterial and antimicrobial agent in consumer products, it can also disrupt the gut microbiome of animals - minnows, zebrafish, rats, mice, and also humans [21]. In mouse models, low doses of TCS exaggerated colonic inflammation and contributed to colon cancer with gut microbiota. Conversely, in mice lacking a gut microbiome or Toll-like receptor 4 - an important molecule for interaction between intestinal microbiota and host physiology, colonic inflammation was not reported after exposure to TCS, indicating an important role of microbiome and TCS in inflammation of the digestive tract. In the mice model, TCS added to HFD, decreased faecal Bacteroidetes and increased Firmicutes, exacerbating dysbiosis of gut microbiota [22]. Similar proportions of these types of microbiota were observed in patients with nonalcoholic steatohepatitis (NASH).

In humans, bacterial diversity in the gut microbiome of infants who received breast milk with detectable triclosan levels was lower compared to the infants exposed to milk containing non-detectable amounts [21]. On the other hand, in in vivo studies, TCS from personal care products did not significantly affect the gut microbiome composition of adults and infants [16]. However, Mahalak et al. reported that the use of high doses of TCS in vitro significantly reduced bacterial population, their diversity, and production of metabolites, mainly in the ascending colon of humans. However, after two weeks, most of the microbiome population and diversity recovered. TCS via binding non-covalently to NAD+ disrupts the synthesis of fatty acids, which are components of cell membranes of bacterias and fungi. Short-chain fatty acids (SCFAs) produced by the gut microbiota, were noted in lower concentration as a bacterial community.

TCS is detected at various concentrations in the tissues of humans and animals, but according to studies, in rats it accumulates mainly in the liver and adipose tissue; therefore, the liver, responsible for detoxification of the body, is an organ exposed to the harmful effects of TCS [23]. In a study on zebrafish, Liu et al. indicated that TCS exposure induces apoptosis of hepatocytes through activation of the MAPK / p53 signaling pathway [23]. Increased expression of both mRNA and protein genes, is associated with significantly reduced expression of anti-apoptotic Bcl-2 mRNA ( $p<0.05$ or $\mathrm{p}<0.01)$ and increased expression of pro-apoptotic Bax $(\mathrm{p}<0.01$ or $\mathrm{p}<0.001)$ [23]. Additionally, TCS exposure increased hepatic weight and lipid accumulation in hepatocytes, which is related to its negative effect on lipid metabolism. Liver injury was also caused by decreased activity of superoxide dismutase (SOD) and an increase in the level of malondialdehyde (MDA) after TCS use. SOD constitutes an important antioxidative component defence against oxidative stress in the body; its reduced level therefore negatively affects hepatocytes. The conducted tests with $\mathrm{H}+$ E staining allowed observation of the atrophy and necrosis of cells. Accumulation of TCS and biotransformation into toxic metabolites may damage the liver, which is detected by a decreased level of ceruloplasmin [10].

The toxic effect of TCS on liver was also demonstrated in the studies on mice, in which TCS combined with a high-fat diet (HFD) significantly attenuated the expression of the regulator of metabolic fibroblast growth factor 21 (FGF21) - cytokine, which has a protective effect on this organ and regulates glucose and lipid metabolism [22]. FGF21 is the target gene for activating the transcription of factor 4 (ATF4), and its action is dependent on the peroxisome proliferator-activated receptor $\alpha$ (PPAR $\alpha$ ). It is supposed that TCS activates PPARa, leading to dysregulating the ATF4/ FGF21 axis and hepatic steatosis in humans.

Carcinogenesis. TCS is considered to be an endocrine disrupting chemical, but not officially as a carcinogen by the International Agency for Research on Cancer (IARC) [24]. By up-regulating the activity of caspase-3 in JEG-3 cells, mouse neocortical neurons, rat neural stem cells, and primary human syncytiotrophoblasts, the proapoptotic properties of TCS were evidenced [1]. On the other hand, TCS promoted the proliferation of mouse epidermis- 
derived JB6 Cl 41-5a cells, via reducing cyclins D1 and A and p27(Kip1) protein levels, which confirmed its potential proliferative action. So far, there is a lack of in vivo human studies on the carcinogenicity of TCS [1]. However, in mice, TCS was reported as a peroxisome proliferator and long-time exposure to TCS contributed to liver fibrosis cirrhosis and development of hepatocellular carcinoma (HCC) $[23,25]$. TCS may induce the expression of drug resistance genes in MHCC97-H cells. The influence of triclosan is based on the clearance of sorafenib in HCC cells treated with TCS, and weakening its anti-proliferative effect in MHCC97-H cells. Exposure to triclosan might be harmful to patients with HCC undergoing chemotherapy [25].

According to Lee, triclosan may play a role in cancer metastasis by inducing the epithelial-mesenchymal transition (EMT) process. The EMT process involves the loss of cell polarity and cell-cell adhesion by epithelial cells. The process acquires a mesenchymal phenotype, which is closely associated with malignant transformation and the initiation of cancer metastasis. Triclosan has the potential to induce cancer metastasis through migration via several signaling pathways associated with the EMT programme, as well as regulating EMT markers [26]. In Lymph Node Carcinoma of the Prostate (LNCaP), cancer cells TCS stimulates cell growth and migration by regulating the cell cycle genes and cathepsin $D$, a gene associated with metastasis, through the AR signaling pathway. Cathepsin D is a group of lysosomal proteases associated with particular features of metastasis in several malignancies, including ovarian, breast, and prostate cancers. Triclosan is considered to induce EMT of ER + MCF breast cancer cells by increasing the expression of $\mathrm{N}$-cadherin, Snail, and Slug, as well as via down-regulation of the protein expression of E-cadherin through ER signaling [26].

TCS as xenoestrogen via an estrogen receptor-dependent pathway can lead to increase in exposure to estradiol, which is known as a risk factor for hormone-dependent neoplasms such as breast and ovarian cancer [1]. TCS induces proliferation of human BG-1 ovarian cells, MCF-7 breast cells, and LNCaP prostate cancer cells. Both in BG-1 and MCF-7 cells, TCS use was associated with an increase in cyclin D1 and reduction of p21 expression. According to studies, blockade of these effects can be possible by inhibition of the estrogen receptor (ER) signaling pathway. Moreover, in MCF-7 cells exposed to TCS, an increase in cyclin E level and decrease in Bax level were noted. Furthermore, TCS increased cathepsin B and D protein expression, which led to the progress of cancer and development of metastasis. However, research into the anti-cancer use of TCS is ongoing.

Alfhili et al. investigated the interaction of TCS with BJAB cells derived from Burkitt's lymphoma without EBV, and outlined the molecular mechanisms specifying its anti-cancer role. Dose-dependent cell death was observed after treatment with 10-100 $\mu \mathrm{M}$ TCS for 24 hours, which was associated with the scrambling of membrane phospholipids, impaired permeability, and cell shrinkage. The research revealed that TCS induced apoptosis in Burkitt's lymphoma cells, at least in part, through deregulated calcium homeostasis, oxidative stress, and nuclear fragmentation. Moreover, the anti-tumour activity of TCS was mediated by caspase and JNK signalling. The TCS concentrations used in the current study are several orders of magnitude lower than those found in consumer products, and are in a range that is cytotoxic to a variety of cells [15].
Endocrine system. Triclosan as a potential endocrine disruptor can affect thyroid function [27]. It was shown in animal studies that triclosan was a cause of low thyroxine concentration, but in humans the effect of triclosan is still unclear. In a cross-sectional study of 317 women, Skarha et al. indicated that a 10 -fold increase in urinary triclosan concentrations was associated with a $-0.06 \mathrm{pg} / \mathrm{mL}$ lower free T3 concentrations (95\% CI: $-0.10,-0.01), 10 \%$ lower TPOAb concentrations (95\% CI: $-19,-0.4$ ), and $12 \%$ lower $\mathrm{TgAb}$ concentrations (95\% CI: $-23,0.9)$. No effect was observed on the concentration of TSH, total T3, or free or total T4. What is more, the concentration of serum-free T3 was connected with urinary triclosan concentration only in women with $\mathrm{BMI}<25 \mathrm{~kg} / \mathrm{m} 2$, but there was no such effect in women with BMI $>25 \mathrm{~kg} / \mathrm{m} 2$. The study suggested that urinary triclosan concentration may be associated with thyroid homeostasis and autoimmunity. Studies in rats show that triclosan can raise sulfotransferase and type 3 deiodinase expression, which regulates the metabolism of T3 to diiodothyronine. This mechanism is compatible with the observation of Skarha et al. In another study, Braun et al. investigated urinary concentration of triclosan and its influence on maternal, neonatal, and child thyroid hormone levels [28]. The study showed that TCS concentration is connected with subsequent thyroid hormone concentration in neonates during delivery and in children, especially in 3-year-olds. Triclosan concentrations during childhood, especially at the age of one, were associated with increased thyroxine concentrations in children at the age of three. There was no impact of triclosan level at maternal thyroid hormone concentration. Further research is necessary to assess the long-term exposure to TCS and its influence on thyroid function.

Animal studies showed that exposure to triclosan can disrupt ovarian function. Chen et al. conducted research on primary rat granulosa cells which were exposed to TCS. They measured the level of estradiol (E2), progesterone (P4), and expression of genes involved in steroidogenesis [29]. The results showed that TCS can increase E2 and P4 levels, and also that this relation depends on time and dose. Moreover, triclosan administered with FSH significantly raised E2 secretion. The level of $\mathrm{P} 4$ also increased but it was significantly lower than the increased E2 level. Studies showed that the secretion of E2 is more sensitive to TCS exposure than P4. To measure gene expression, they treated rats' primary granulosa cells for $24 \mathrm{~h}$ with triclosan. After that, they selected 11 genes, nine of which were responsible for ovarian steroidogenesis and two were significantly expressed. Next, they performed qRT-PCR. The results showed that for P4-related genes their expression was varied, Star was upregulated while Cyp11a1 was downregulated. For E2-related genes, expression significantly increased in Hsd17ß1, Cyp19a1, Cypla1, and Cyp1b1. Treatment with triclosan plus FSH significantly increased the levels of CYP19A1 (aromatase) $(\mathrm{p}<0.05)$.

In conclusion, triclosan can up-regulate the steroidogenesis pathway. Triclosan raises StAR (Star) and aromatase (Cyp19a1) protein. Chen et al. hypothesised that triclosan can stimulate the steroidogenesis pathway through $\mathrm{GnRH}$ (cAMP/PKA) signalling, where cAMP/PKA might influence up-regulation of StAR (Star) and aromatase (Cyp19a1). The rise in $\mathrm{P} 4$ concentration might be caused by increased expression of StAR, while the E2 up-regulation could be related to an increased expression of aromatase [29]. 
Another study of cultured swine luteal cells showed that triclosan disturbs the physiological function of the corpus luteum, which is necessary for a proper ovarian cyclicity. Triclosan significantly inhibited the proliferation of luteal cells and luteal cell metabolic activity without significant difference between all tested concentrations (1, 10, and 50 $\mu \mathrm{M})$, and inhibited luteal cell progesterone production at the highest concentration tested [30]. The influence of TCS on the hypothalamic-pituitary-ovarian axis was noted in a Chinese analysis of 84 infertile women with polycystic ovary syndrome (PCOS, and 212 infertile controls without PCOS aged 18-45. Triclosan levels and LH (luteinizing hormone) and LH/FSH (follicle-stimulating hormone) ratio in nonPCOS women were positively correlated [31].

Triclosan exposure during gestation and lactation have a detrimental effect on reproductive functions and fertility of next-generation male rats. Different doses of TCS $(0.1,4$, 40 , and $150 \mathrm{mg} / \mathrm{kg} \mathrm{b}$. wt./day) were given to pregnant female rats during gestation day six to postnatal day 21 . Perturbed expression of steroid hormone receptors, steroidogenic acute regulatory protein (StAR), and aromatase in the F1 male rats at postnatal day 75 were observed [32]. Another animal study showed that doses of $0 \mathrm{mg}, 3 \mathrm{mg}$, and $5 \mathrm{mg} \mathrm{TCS} / \mathrm{kg} /$ day given to lactating female rats through the first 28 days after delivery, significantly decreased mRNA levels for $3 \beta$ hydro-hydroxysteroid dehydrogenases (3ßHSD), OCT3/4, and androgen receptor $(A R)$ among the male offspring [33]. A study of 537 healthy pregnant women in China showed that exposure to triclosan (detected in the urine) might potentially affect some parameters of newborns. Prenatal TCS levels $>0.6 \mu \mathrm{g} / \mathrm{L}$ resulted in about $0.23 \mathrm{ng} / \mathrm{mL}$ higher testosterone concentrations in the blood from an umbilical cord, compared to those with levels $<0.1 \mu \mathrm{g} / \mathrm{L}$ (95\% CI: 0.05, $0.45 ; \mathrm{p}=0.02)$. Furthermore, TCS decreased steroidogenic enzyme levels in the placenta: aromatase cytochrome P450 (P450arom), 17 $\beta$-hydroxysteroid dehydrogenase (17 $\beta$-HSD), and $3 \beta$-HSD. These effects were more visibly observed in male infants who also presented with decreased estradiol levels in umbilical cord blood [34]. A summary of the potential influence of triclosan on human health is presented in Table 1.

Table 1. Summary of effects of triclosan on human health [12-19, 21-22, 25-34]

\begin{tabular}{|c|c|c|c|c|c|}
\hline Authors & Type of study & Country & $\begin{array}{l}\text { Study group/ } \\
\text { research } \\
\text { material }\end{array}$ & Results & Conclusions \\
\hline \multicolumn{6}{|c|}{ Antimicrobial activity } \\
\hline Ahmed I. et al. & $\begin{array}{l}\text { Systematic } \\
\text { review and } \\
\text { meta-analysis of } \\
25 \text { RCTs }\end{array}$ & UK & $\begin{array}{l}11,957 \\
\text { participants }\end{array}$ & $\begin{array}{l}\text { - TCS-coated sutures maningly reduced the risk of } \\
\text { surgical site infections (SSI) within } 30 \text { days in both } \\
\text { clean and contaminated surgery }\end{array}$ & $\begin{array}{l}\text { - the use of TCS-coated sutures is recommended } \\
\text { in order to reduce the risk of SSIs in clean and } \\
\text { contaminated surgical procedures }\end{array}$ \\
\hline Zeng W. et al. & $\begin{array}{l}\text { Experimental } \\
\text { study, in vitro }\end{array}$ & China & $\begin{array}{l}200 \text { E. coli } \\
\text { isolates }\end{array}$ & $\begin{array}{l}-2.5 \% \text { of } E \text {. coli isolates were resistant to TCS } \\
\text { (multidrug resistance and cross-resistance } \\
\text { phenotypes), } \\
-5 \text { susceptible } E \text {. coli isolates rapidly enhanced TCS } \\
\text { resistance } 12 \text { days after exposure to subinhibitory TCS } \\
\text { concentration in vitro }\end{array}$ & $\begin{array}{l}\text { - TCS contributes to the acquisition of resistance } \\
\text { to this substance, and facilitates the reduction of } \\
\text { sensitivity to clinical antimicrobials }\end{array}$ \\
\hline Yang L. et al. & $\begin{array}{l}\text { Experimental } \\
\text { study }\end{array}$ & China & Murine model & $\begin{array}{l}\text { - Obtained nanoantibiotics based on TCS and self- } \\
\text { assemble peptides had many advantages: a stable } \\
\text { 3-dimensional structure of nanofibers; } 850 \text {-fold } \\
\text { increase in TCS solubility; acid-responsive TCS release; } \\
\text { favourable biocompatibility }\end{array}$ & $\begin{array}{l}\text { - hydrogel nanoantibiotics exhibited enhanced } \\
\text { in vitro antibacterial activities through the } \\
\text { bacterial membrane disruption caused by } \\
\text { the hydrogel nanofiber structure and the } \\
\text { antibacterial properties of the TCS released in } \\
\text { weakly acidic environments }\end{array}$ \\
\hline \multicolumn{6}{|c|}{ Metabolism, immunity } \\
\hline $\begin{array}{l}\text { Weatherly LM } \\
\text { et al. }\end{array}$ & $\begin{array}{l}\text { Experimental } \\
\text { study }\end{array}$ & USA & murine model & $\begin{array}{l}\text { - Dermal exposure to TCS led to activating NLRP3 } \\
\text { inflammasome in vivo, caspase- } 1 \text { activation, mature } \\
\text { IL-1 } \beta \text { secretion in the skin and draining lymph nodes } \\
\text { (dLNs), decreased mitochondrial mass (mtMass), } \\
\text { mitochondrial membrane potential (MMP) }\end{array}$ & $\begin{array}{l}\text { - Inflammation induced by NLRP3 activation can } \\
\text { increase the risk of allergic diseases } \\
\text { - Triclosan as an immunomodulator induced } \\
\text { modulation of chemokine release, mitochondrial } \\
\text { fission and dysfunction }\end{array}$ \\
\hline $\begin{array}{l}\text { Mahalak KK } \\
\text { et al. }\end{array}$ & $\begin{array}{l}\text { Experimental } \\
\text { study, in vitro }\end{array}$ & USA & $\begin{array}{l}\text { samples from } \\
\text { an American }\end{array}$ & $\begin{array}{l}\text { - High doses of TCS influenced gut microbial diversity } \\
\text { in vitro } \\
\text { - Reduction of synthesis of short-chain fatty acids } \\
\text { (SCFAs) and bile acid conversion }\end{array}$ & $\begin{array}{l}\text { - TCS from consumer products may be related to } \\
\text { development of inflammatory bowel disease }\end{array}$ \\
\hline $\begin{array}{l}\text { Sanidad KZ } \\
\text { et al. }\end{array}$ & Review & USA & animal model & $\begin{array}{l}\text { - Exposure to TCS intensify colon inflammation } \\
\text { and accelerates the development of colon cancer } \\
\text { associated with colitis (gut microbiome is essential for } \\
\text { the proinflammatory effects of TCS) }\end{array}$ & $\begin{array}{l}\text { - TCS might have adverse effects on the gut } \\
\text { health and microbiome }\end{array}$ \\
\hline Liang $Y$ et al. & $\begin{array}{l}\text { Experimental } \\
\text { study }\end{array}$ & China & cell model & $\begin{array}{l}\text { - TCS induced changes in metabolism in human } \\
\text { HaCaT keratinocytes: increase of purine and GSH } \\
\text { metabolism, decrease of amino acid metabolism, } \\
\text { dysregulation of lipid metabolism and oxidative stress }\end{array}$ & $\begin{array}{l}\text { - Topical use of TCS can have prooxidative and } \\
\text { proapoptotic action }\end{array}$ \\
\hline $\begin{array}{l}\text { Sangroula S } \\
\text { et al. }\end{array}$ & $\begin{array}{l}\text { Experimental } \\
\text { study }\end{array}$ & USA & cell model & $\begin{array}{l}\text { - TCS exposure resulted in cytosolic acidification in } \\
\text { mast cells and T cells, inhibition Ca2+ mobilization in } \\
\text { human Jurkat T cells, and reduction of MMP due to its } \\
\text { ionophoric activity }\end{array}$ & $\begin{array}{l}\text { - Inhibition Ca2+ influx disrupts mast cell } \\
\text { signaling and function of immune system }\end{array}$ \\
\hline
\end{tabular}


Table 1. Summary of effects of triclosan on human health [12-19, 21-22, 25-34] (continuation)

\begin{tabular}{|c|c|c|c|c|c|}
\hline Authors & Type of study & Country & $\begin{array}{l}\text { Study group/ } \\
\text { research } \\
\text { material }\end{array}$ & Results & Conclusions \\
\hline Yueh MF. et al. & $\begin{array}{l}\text { Experimental } \\
\text { study }\end{array}$ & USA & Animal model & $\begin{array}{l}\text { - TCS impairs expression of the metabolic regulator } \\
\text { fibroblast growth factor } 21 \text { induced by high-fat diet } \\
\text { in the liver } \\
\text { - TCS reduces microflora diversity which resembles } \\
\text { changes in microbiota in nonalcoholic steatohepatitis } \\
\text { patients }\end{array}$ & $\begin{array}{l}\text { - TCS potentiates and accelerates the } \\
\text { development of steatohepatitis and fibrosis, } \\
\text { accompanied by increased levels of hepatic lipid } \\
\text { droplets and oxidative stress }\end{array}$ \\
\hline \multicolumn{6}{|l|}{ Carcinogenesis } \\
\hline Wu M. et al. & $\begin{array}{l}\text { Experimental } \\
\text { study }\end{array}$ & China & Animal model & $\begin{array}{l}\text { - TCS could impair the anti-proliferation effect of } \\
\text { sorafenib, induce the expression of drug-resistance } \\
\text { genes in MHCC97-H cells (a highly aggressive HCC cell } \\
\text { line), as well as promote the clearance of sorafenib }\end{array}$ & $\begin{array}{l}\text { - exposure of TCS during chemotherapy might } \\
\text { accelerate the clearance of sorafenib and induces } \\
\text { sorafenib resistance in HCC cell line and in } \\
\text { vivo tumor models; it could be harmful to HCC } \\
\text { patients }\end{array}$ \\
\hline Lee HM. at al. & Review & $\begin{array}{l}\text { Republic } \\
\text { of Korea }\end{array}$ & Not applicable & $\begin{array}{l}\text { - TCS increased the expression of N-cadherin, Snail } \\
\text { and Slug, as well as downr-regulation of the protein } \\
\text { expression of E-cadherin through ER signaling, which } \\
\text { induced epithelial-mesenchymal transition (EMT) of } \\
\text { ER + MCF breast cancer cells, } \\
\text { - TCS stimulates cell growth and migration in Lymph } \\
\text { Node Carcinoma of the Prostate cancer cells by } \\
\text { regulating the cell cycle genes and cathepsin D }\end{array}$ & $\begin{array}{l}\text { - TCS has the potential to induce cancer } \\
\text { metastasis through migration via several } \\
\text { signaling pathways associated with the } \\
\text { epithelial-mesenchymal transition process and } \\
\text { regulating EMT markers }\end{array}$ \\
\hline $\begin{array}{l}\text { Alfhili MA. } \\
\text { et al. }\end{array}$ & $\begin{array}{l}\text { Experimental } \\
\text { study }\end{array}$ & $\begin{array}{l}\text { Saudi- } \\
\text { Arabia }\end{array}$ & Cell model & $\begin{array}{l}\text { - TCS induced dose-dependent apoptosis in Burkitt's } \\
\text { lymphoma cells, at least in part, through deregulated } \\
\text { calcium homeostasis, oxidative stress, and nuclear } \\
\text { fragmentation }\end{array}$ & $\begin{array}{l}\text { - TCS has antitumor properties through } \\
\text { molecular mechanisms governing TCS-induced } \\
\text { apoptosis in BL cells }\end{array}$ \\
\hline \multicolumn{6}{|c|}{ Endocrine system / hormones } \\
\hline Skarha J. et al. & $\begin{array}{l}\text { Cross-sectional } \\
\text { study }\end{array}$ & USA & 317 women & $\begin{array}{l}\text { - } 10 \text {-fold increase in urinary TCS concentrations } \\
\text { was associated with a }-0.06 \mathrm{pg} / \mathrm{mL} \text { lower free T3 } \\
\text { concentrations, } 10 \% \text { lower TPOAb concentrations and } \\
12 \% \text { lower TgAb concentrations, } \\
\text {-Concentration of serum-free T3 was connected with } \\
\text { urinary TCS concentration only in women with } \mathrm{BMI}< \\
25 \mathrm{~kg} / \mathrm{m} 2\end{array}$ & $\begin{array}{l}\text { - TCS can influence thyroid homeostasis and } \\
\text { autoimmunity }\end{array}$ \\
\hline $\begin{array}{l}\text { Braun JM. } \\
\text { et al. }\end{array}$ & $\begin{array}{l}\text { Prospective } \\
\text { cohort study }\end{array}$ & USA & $\begin{array}{l}\text { Mothers at } \\
\text { 16-weeks } \\
\text { gestation } \\
(\mathrm{n}=202) \text {, } \\
\text { neonates at } \\
\text { delivery }(\mathrm{n}= \\
\text { 274), children } \\
\text { at age } 3 \text { years } \\
(\mathrm{n}=153)\end{array}$ & $\begin{array}{l}\text { - TCS concentration is connected with subsequent } \\
\text { thyroid hormone concentration at neonates at } \\
\text { delivery and children, especially at } 3 \text { years old, } \\
\text { - Childhood TCS, mainly at age } 1 \text { year, was associated } \\
\text { with increased thyroxine concentrations in children at } \\
\text { age } 3 \text { years }\end{array}$ & $\begin{array}{l}\text { - TCS exposure may influence some features of } \\
\text { neonatal and early child thyroid function }\end{array}$ \\
\hline Chen W. et al. & $\begin{array}{l}\text { Experimental } \\
\text { study }\end{array}$ & China & Cell model & $\begin{array}{l}\text { - TCS increased estradiol (E2) and progesterone (P4) } \\
\text { production, this relation depends on time and dose } \\
\text { - TCS administered with FSH significantly raised E2 } \\
\text { secretion, }\end{array}$ & $\begin{array}{l}\text {-Secretion of E2 is more sensitive to TCS } \\
\text { exposure than } \mathrm{P} 4 \text {, } \\
\text { - triclosan can up-regulate the steroidogenesis } \\
\text { pathway }\end{array}$ \\
\hline Basini G. et al. & $\begin{array}{l}\text { Experimental } \\
\text { study }\end{array}$ & Italy & $\begin{array}{l}\text { In vitro (swine } \\
\text { luteal cells) }\end{array}$ & $\begin{array}{l}\text { - TCS disturbs the physiological function of the corpus } \\
\text { luteum } \\
\text { - TCS significantly inhibited the proliferation of luteal } \\
\text { cells and luteal cell metabolic activity, and inhibited } \\
\text { luteal cell progesterone production }\end{array}$ & $\begin{array}{l}\text { - TCS interferes with the main physiological } \\
\text { function of corpus luteum }\end{array}$ \\
\hline Ye J. et al. & $\begin{array}{l}\text { Cross-sectional } \\
\text { study }\end{array}$ & China & $\begin{array}{l}84 \text { infertile } \\
\text { women with } \\
\text { PCOS and } \\
212 \text { infertile } \\
\text { controls } \\
\text { without PCOS }\end{array}$ & $\begin{array}{l}\text { - Positive correlation between TCS levels and LH } \\
\text { (luteinizing hormone) and LH/FSH (follicle-stimulating } \\
\text { hormone) ratio in non-PCOS women }\end{array}$ & $\begin{array}{l}\text { - exposure to TCS is associated with PCOS at a } \\
\text { comparatively low level among Chinese women }\end{array}$ \\
\hline Priyanka et al. & $\begin{array}{l}\text { Experimental } \\
\text { study }\end{array}$ & India & $\begin{array}{l}\text { Animal study } \\
\text { (male rats) }\end{array}$ & $\begin{array}{l}\text {-Perturbed expression of steroid hormone receptors, } \\
\text { steroidogenic acute regulatory protein (StAR), and } \\
\text { aromatase in the F rats }\end{array}$ & $\begin{array}{l}\text { - TCS exposure during gestation and lactation } \\
\text { have a detrimental effect on reproductive } \\
\text { functions of next-generation rats }\end{array}$ \\
\hline $\begin{array}{l}\text { Mandal TK. } \\
\text { et al. }\end{array}$ & $\begin{array}{l}\text { Experimental } \\
\text { study }\end{array}$ & India & $\begin{array}{l}\text { Animal study } \\
\text { (lactating } \\
\text { female rats) }\end{array}$ & $\begin{array}{l}\text { - TCS from mother rat's milk significantly decreased } \\
\text { mRNA levels for } 3 \beta \text { hydro-hydroxysteroid } \\
\text { dehydrogenases (3ßHSD), OCT3/4, and androgen } \\
\text { receptor (AR) among male offspring }\end{array}$ & $\begin{array}{l}\text { - TCS given to lactating female rats acts as a } \\
\text { potential endocrine stimulator in the formation } \\
\text { of Leydig cells, spermatogonia, and gonocytes of } \\
\text { their male offspring }\end{array}$ \\
\hline Wang C. et al. & $\begin{array}{l}\text { Prospective } \\
\text { Cohort study }\end{array}$ & China & $\begin{array}{l}537 \text { pregnant } \\
\text { women }\end{array}$ & $\begin{array}{l}\text { - Prenatal TCS levels }>0.6 \mu \mathrm{g} / \mathrm{L} \text { results in about } 0.23 \\
\mathrm{ng} / \mathrm{mL} \text { higher testosterone concentrations in the } \\
\text { blood from an umbilical cord compared to those with } \\
\text { levels }<0.1 \mu \mathrm{g} / \mathrm{L} \\
\text { - TCS decreased steroidogenic enzyme levels in the } \\
\text { placenta: } \mathrm{P} 450 \text { arom, } 17 \beta-\mathrm{HSD} \text {, and } 3 \beta-\mathrm{HSD} \\
\text { - Male infants who presented with decreased estradiol } \\
\text { levels in blood from umbilical cord }\end{array}$ & $\begin{array}{l}\text { - exposure to TCS among Pregnant woman } \\
\text { might potentially affect reproductive hormones } \\
\text { in cord blood mediated by steroidogenic } \\
\text { enzymes of newborns }\end{array}$ \\
\hline
\end{tabular}




\section{CONCLUSIONS}

Analysis of current research indicated that triclosan has adverse effects on various molecular pathways in different organs. Due to the widespread use of triclosan in consumer goods and ubiquity in the environment, it is important to understand the underlying mechanisms of the action of triclosan and its impact on the human body. Personal care products and cosmetics are more commonly used by women; therefore, exposure to their components is generally higher in women than in men. Triclosan is a potentially harmful substance that requires special attention from researchers. The effect of triclosan on the human body, particularly on carcinogenesis and human fertility, requires further, in-depth analysis. Additionally, more research is needed to develop the use of TCS as a safe and useful antimicrobial agent.

\section{REFERENCES}

1.Alfhili MA, Lee MH. Triclosan: an update on biochemical and molecular mechanisms. Oxid Med Cell Longev. 2019;2019:1607304. doi: 10.1155/2019/1607304.

2.Zhu W, Zhou W, Huo X, et al. Triclosan and female reproductive health: a preconceptional cohort study. Epidemiology. 2019 Jul; 30 Suppl 1: S24-S31. doi: 10.1097/EDE.0000000000001011

3. Karnas K, Marotta J, Koseki R, et al. Triclosan resistance derived across environmentally and clinically relevant gram negative bacteria. Journal of the Pennsylvania Academy of Science. 2019; 93(2): 83-106. doi: 10.5325/jpennacadscie.93.2.0083

4. Henriksen NA, Deerenberg EB, Venclauskas L, et al. Triclosan-coated sutures and surgical site infection in abdominal surgery: the TRISTAN review, meta-analysis and trial sequential analysis. Hernia. 2017;21(6): 833-841. doi: 10.1007/s10029-017-1681-0

5. Yamashita K, Takeno S, Hoshino S, et al. Triclosan sutures for surgical site infection in colorectal cancer. J Surg Res. 2016; 206(1): 16-21. doi: 10.1016/j.jss.2016.06.070

6. McFarland AG, Bertucci HK, Littman E, et al. Triclosan tolerance is driven by a conserved mechanism in diverse Pseudomonas species. Appl Environ Microbiol. 2021; 87(7): e02924-20. doi: 10.1128/AEM.02924-20

7. Ayyash M, Shehabi AA, Mahmoud NN, et al. Antibiofilm properties of triclosan with EDTA or cranberry as Foley Catheter lock solutions. J Appl Microbiol. 2019; 127(6): 1876-1888. doi: 10.1111/jam.14439

8. Mihaich E, Capdevielle M, Urbach-Ross D, et al. Hypothesis-driven weight-of-evidence analysis of endocrine disruption potential: a case study with triclosan. Crit Rev Toxicol. 2017; 47(4): 263-285. doi: 10.1080/10408444.2016.1269722

9. Karwacka A, Zamkowska D, Radwan M, et al. Exposure to modern, widespread environmental endocrine disrupting chemicals and their effect on the reproductive potential of women: an overview of current epidemiological evidence. Hum Fertil (Camb). 2019; 22(1): 2-25. doi: 10.1080/14647273.2017.1358828

10. Bera KK, Kumar S, Paul T, et al. Triclosan induces immunosuppression and reduces survivability of striped catfish Pangasianodon hypophthalmus during the challenge to a fish pathogenic bacterium Edwardsiella tarda. Environ Res. 2020; 186: 109575. doi: 10.1016/j. envres.2020.109575

11. Jurewicz J, Wielgomas B, Radwan $M$, et al. Triclosan exposure and ovarian reserve. Reprod Toxicol. 2019; 89: 168-172. doi: 10.1016/j. reprotox.2019.07.086

12. Zeng W, Xu W, Xu Y, et al. The prevalence and mechanism of triclosan resistance in Escherichia coli isolated from urine samples in Wenzhou, China. Antimicrob Resist Infect Control. 2020; 9(1): 161. doi: 10.1186/ s13756-020-00823-5

13. Ahmed I, Boulton AJ, Rizvi S, et al. The use of triclosan-coated sutures to prevent surgical site infections: a systematic review and metaanalysis of the literature. BMJ Open. 2019; 9(9): e029727. doi: 10.1136/ bmjopen-2019-029727
14. Yang L, Zhang C, Huang F, et al. Triclosan-based supramolecular hydrogels as nanoantibiotics for enhanced antibacterial activity. J Control Release. 2020; 324: 354-365. doi: 10.1016/j.jconrel.2020.05.034

15. Alfhili MA, Hussein HAM, Park Y, et al. Triclosan induces apoptosis in Burkitt lymphoma-derived BJAB cells through caspase and JNK/ MAPK pathways. Apoptosis. 2021; 26(1-2): 96-110. doi: 10.1007/s10495020-01650-0.

16. Mahalak KK, Firrman J, Lee JJ, et al. Triclosan has a robust, yet reversible impact on human gut microbial composition in vitro. PLoS One. 2020; 15(6): e0234046. doi: 10.1371/journal.pone.0234046

17. Liang Y, Zhang H, Cai Z. New insights into the cellular mechanism of triclosan-induced dermal toxicity from a combined metabolomic and lipidomic approach. Sci Total Environ. 2021; 757: 143976. doi: 10.1016/j. scitotenv.2020.143976

18. Weatherly LM, Shane HL, Friend SA, et al. Topical application of the antimicrobial agent triclosan induces NLRP3 inflammasome activation and mitochondrial dysfunction. Toxicol Sci. 2020; 176(1): 147-161. doi: 10.1093/toxsci/kfaa056

19. Sangroula S, Baez Vasquez AY, Raut P, et al. Triclosan disrupts immune cell function by depressing Ca2+ influx following acidification of the cytoplasm. Toxicol Appl Pharmacol. 2020; 405: 115205. doi: 10.1016/j. taap.2020.115205

20.Zhang M, Zhu R, Zhang L. Triclosan stimulates human vascular endothelial cell injury via repression of the PI3K/Akt/mTOR axis. Chemosphere. 2020;241: 125077. doi: 10.1016/j.chemosphere.2019.125077

21. Sanidad KZ, Xiao H, Zhang G. Triclosan, a common antimicrobial ingredient, on gut microbiota and gut health. Gut Microbes. 2019; 10(3): 434-437. doi: 10.1080/19490976.2018.1546521

22. Yueh MF, He F, Chen C, et al. Triclosan leads to dysregulation of the metabolic regulator FGF21 exacerbating high fat diet-induced nonalcoholic fatty liver disease. Proc Natl Acad Sci USA. 2020; 117(49): 31259-31266. doi: 10.1073/pnas.2017129117

23. Liu M, Ai W, Sun L, et al. Triclosan-induced liver injury in zebrafish (Danio rerio) via regulating MAPK/p53 signaling pathway. Comp Biochem Physiol C Toxicol Pharmacol. 2019; 222: 108-117. doi: 10.1016/j. cbpc.2019.04.016

24. Lee JD, Lee JY, Kwack SJ, et al. Risk assessment of triclosan, a cosmetic preservative. Toxicol Res. 2019; 35(2): 137-154. doi: 10.5487/ TR.2019.35.2.137

25. Wu M, Zhao G, Zhuang X, et al. Triclosan treatment decreased the antitumor effect of sorafenib on hepatocellular carcinoma cells. Onco Targets Ther. 2018; 11: 2945-2954. doi: 10.2147/OTT.S165436

26. Lee HM, Hwang KA, Choi KC. Diverse pathways of epithelial mesenchymal transition related with cancer progression and metastasis and potential effects of endocrine disrupting chemicals on epithelial mesenchymal transition process. Mol Cell Endocrinol. 2017; 457: $103-$ 113. doi: 10.1016/j.mce.2016.12.026

27. Skarha J, Mínguez-Alarcón L, Williams PL, et al. Cross-sectional associations between urinary triclosan and serum thyroid function biomarker concentrations in women. Environ Int. 2019; 122: 256-262. doi: 10.1016/j.envint.2018.11.015

28. Braun JM, Chen A, Hoofnagle A, et al. Associations of early life urinary triclosan concentrations with maternal, neonatal, and child thyroid hormone levels. Horm Behav. 2018; 101: 77-84. doi: 10.1016/j. yhbeh.2017.11.009

29. Chen W, Yang X, Wang B, et al. The effects and possible mechanisms of triclosan on steroidogenesis in primary rat granulosa cells. Reprod Toxicol. 2019; 83: 28-37. doi: 10.1016/j.reprotox.2018.11.001

30. Basini G, Bussolati S, Bertini S, et al. Evaluation of triclosan effects on cultured swine luteal cells. Animals (Basel). 2021; 11(3): 606. doi: 10.3390/ani11030606

31. Ye J, Zhu W, Liu H, et al. Environmental exposure to triclosan and polycystic ovary syndrome: a cross-sectional study in China. BMJ Open. 2018; 8(10): e019707. doi: 10.1136/bmjopen-2017-019707

32. Priyanka, Trivedi A, Maske P, et al. Gestational and lactational exposure to triclosan causes impaired fertility of F1 male offspring and developmental defects in F2 generation. Environ Pollut. 2020; 257: 113617. doi: 10.1016/j.envpol.2019.113617

33. Mandal TK, Parvin N, Joo SW, et al. Risk assessment of cosmetics using triclosan on future generation's germ cell maturation via lactating mother rats. Int J Environ Res Public Health. 2020; 17(4): 1143. doi: $10.3390 /$ ijerph 17041143

34. Wang C, Chen L, Zhao S, et al. Impacts of prenatal triclosan exposure on fetal reproductive hormones and its potential mechanism. Environ Int. 2018; 111: 279-286. doi: 10.1016/j.envint.2017.11.007 